\title{
Religious Reasons and Motives for The Phenomenon of Excluding Scholars in The Arab Islamic State in The Abbasid Era
}

\author{
Hind Fadel Salih Mahmoud*, Siham Jamil Jassim \\ Department of History, Collage of Education for Women, University of Anbar, Iraq \\ * hendfadel1988@gmail.com
}

\section{KEYWORDS: $\quad$ Exclusion, Scholars, Religious Motives, Abbasid Era, Heretics.}

\begin{abstract}
:
Despite the great position that the scholars enjoyed in the Arab Islamic state, especially in the Abbasid era' where the successors of this state were interested in science and scholars, and Islamic culture reached its peak in this era, but many scholars were subjected to exclusion and persecution in the Abbasid era' and the motives that were many It led to their expulsion, and the religious motive was one of the most important motives that led to the exclusion of scholars, and the exclusion decisions varied in terms of positivity and negativity. For example, the decision to exclude scholars who were accused of heresy was one of the right decisions that brought positive results to the Arab Islamic state, so the state got rid of Heretics and destructive ideas that would destroy the Islamic community. As for the negative decisions to exclude scholars, they were excluded from the plight of creating the Qur'an that negatively affected the Islamic state. Their loss was the most important negative impact of the plight of creating the Qur'an.
\end{abstract}


الأسباب والدو افع الدينية لظاهرة إقصاء العلماء في الدولة العربية الإسلامية في العصر العباسي

$$
\begin{aligned}
& \text { هند فاضل صالح محمود"، أ.د. سهام بحيل جاسم } \\
& \text { قسم التاريخ، كلية التربية للبنات، جامعة الأنبار، العراق } \\
& \text { * hendfadel1988@gmail.com }
\end{aligned}
$$

$$
\text { الكلمات المفتاحية | إقصاء، العلماء، الدوافع الدينية، العصر العباسي، الزنادقة. }
$$

\begin{tabular}{l|l} 
Crossref doi & https://doi.org/10.51345/.v32i2.372.g214
\end{tabular}

\section{ملخص البحث:}

على الرغم من المكانة الكبيرة التي تمتع بها العلماء في الدولة العربية الإسلامية، وخاصة في العصر العباسي إذ كان الخلفاء مهتمين بالعلم والعلماء، وبلغت الثقافة العربية الإسلامية ذروما في هذا العصر؛ وذلك لأنفتاحها على بقية الأمم والشعوب إلى إلى محققاً تمازجاً ثقافياً، إلا أن العديد من العلماء تعرضوا للإقصاء والاضطهاد في العصر العباسي، والدوافع التي كانت كثيرة أدت إلى طردهم، وكان الدافع الديني من أهم الدوافع التي أدت إلى إقصاء العلماء، وتباينت قرارات الإقصاء من حيث الإيجابية والسلبية. على سبيل المثال، كان قرار استبعاد العلماء المتهمين بالهرطقة من القرارات الصائبة التي جاءت بندي بنتائج إيجابية للدولة

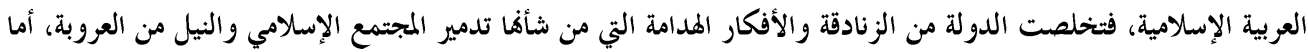
القرارات السلبية باقصاء العلماء، وتحديداً في محنة خلق القر آن الذي أثثرت سلباً على الدولة العربية الإسلامية.

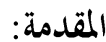

حظي العلماء .مكانة مرموقة في الدولة العربية الإسلامية ولاسيما في العصر العباسي، وعلى الرغم من هذه المكانة الكبيرة إلا ان البعض منهم تعرض للإقصاء و تعددت اسباب ودوافع هذه الاقصاءات. فتح بكثت دراستنا في (الاسباب والدوافع الدينية لظاهرة اقصاء العلماء في الدولة العربية الاسلامية في

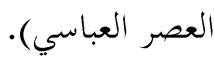
و حاول الباحث الاجابة عن علّة تساؤلات أهمها: هل ان هميع حالات الاقصاء التي تعرض هلا العلماء في العصر العباسي كانت صائبة بين قوها وفرضت هيبتها؟ اما على العكس كانت خاطئب؟ وهل كانت الدوافع الدينية حقيقية، ام تكمن ورائها اسباب اخرى ادت الى ذلك الاقصاء، سيحاول الباحث الاجابة على هذه التساؤلات من خلال جمع الروايات التاريخية وتحليلها من اجل الوصول والاقتراب من الحقيقة التاريخية قدر المستطاع. 
وتتلخص اهمية هذه الدراسة بأها سلطت الضوء على شريحة مهمة من شرائح المجتمع العربي الاسلامي و بينت حقيقة الدافع الديني الذي ادى الى اقصائهم.

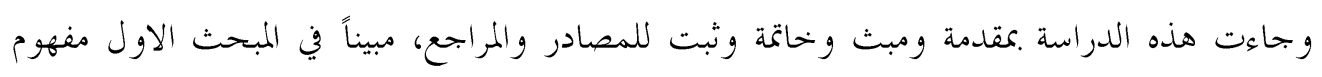

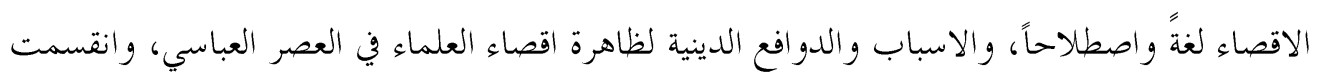

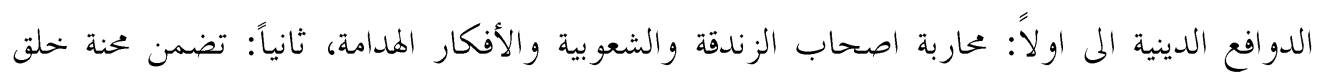
القرآن التي ظهرت في عهد الخليفة المأمون واستمرت لعدة خحلفاء بعلده.

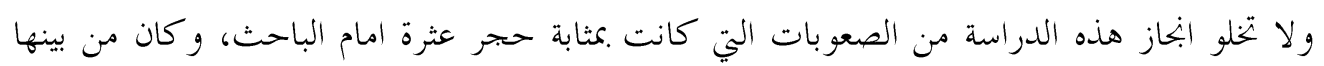

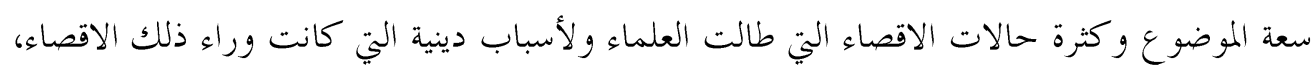

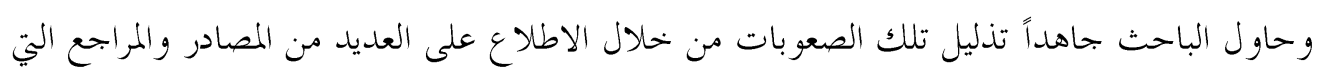
تطرقت و تضمنت الروايات التاريخية عن هذا الموضو ضوع.

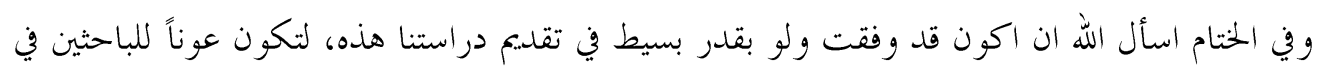
بحال التاريخ العربي الاسلامي.

\section{المبحث الإول: مفهوم الاقصاء

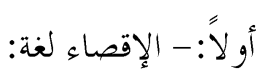

وردت لفظة الاقصاء في المعاجم العربية بصيغ متعددة لكنها ذات معنى واحد، وهي الإقصاء، واقصيٌ الإهي

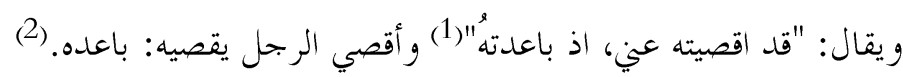

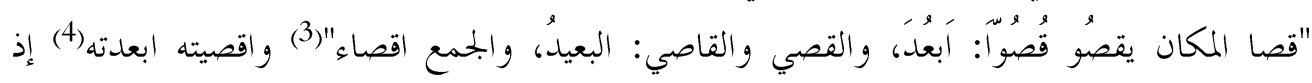

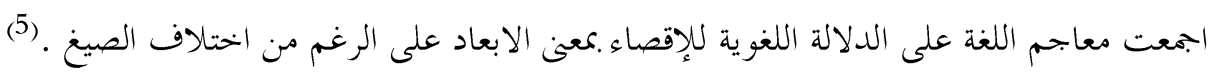
ثانياً: -الإقصاء اصطلاحاً:

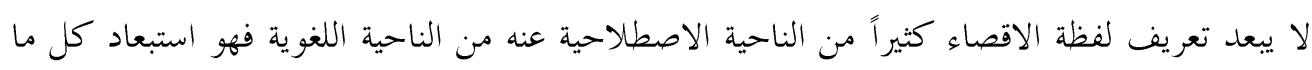

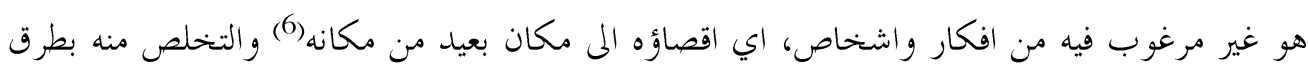
واساليب مختلفة.

الأسباب والدوافع الدينية لظاهرة اقصاء العلماء في العصر العباسي

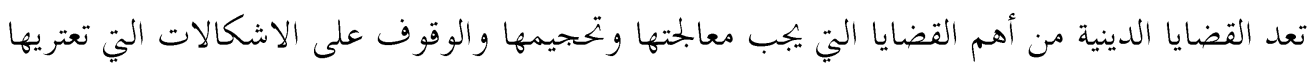

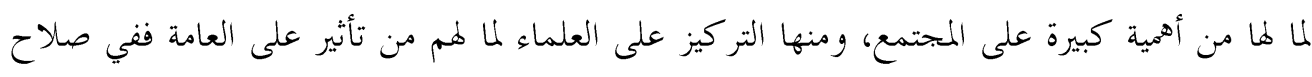




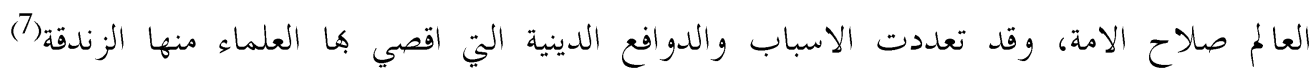

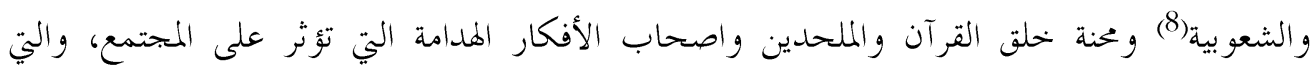
سنتناولها باييجاز و.بما يخدم دراستنا.

\section{أولاً: محاربة اصحاب الزندقة والشعوبية والافكار المدامة:}

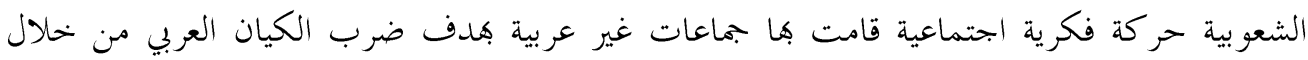

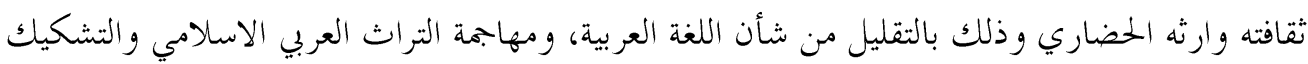
بلدور العرب التاريخي والاستهزاء بالقيم والمثل العربية، مقابل الاعتزاز بالإرث الاعجمي وتمجيد القيم تهريم

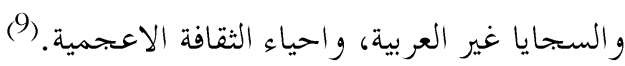
فالزندقة مظهر اساس من مظاهر الشعوبية وهي اعلى مراحل التحدي الديني والفكري والاجتماعي للإسلام التي استهدفت هدم الاسلام في الداخل لان الشعوبية قد ادركت العلاقة العضوية بين العروبة وندية

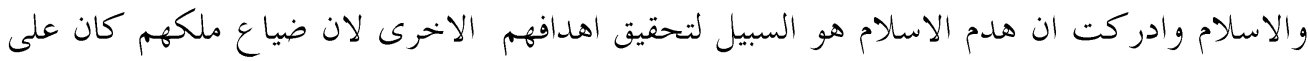

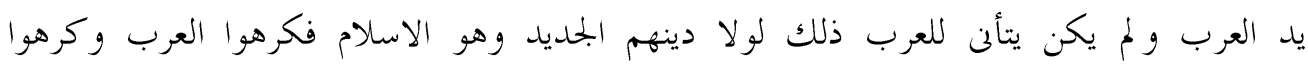

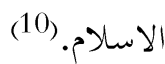

هج الخلفاء العباسيين منهجاً واضحاً منذ بداية خلافتهم في مواجهة الزنادقة والشعوبيين والملحدين

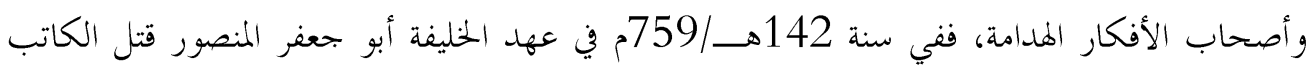

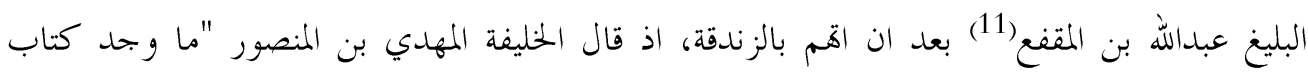

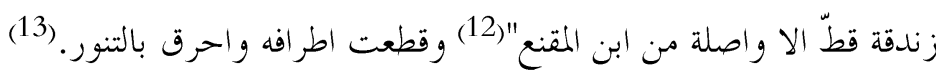

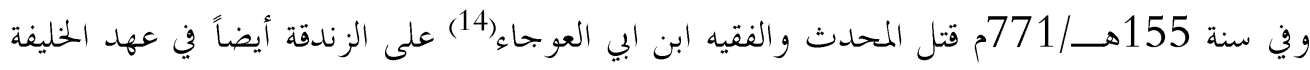
ابو جعفر المنصور واعترف قبل قتله بوضع أربعة آلاف حديث حلل فيه الحرام، وحرم فيه الحلال، ويصوم الناس يوم الفطر ويفطرهم في أيام الصيام. (15)

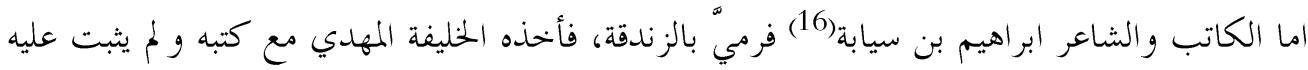

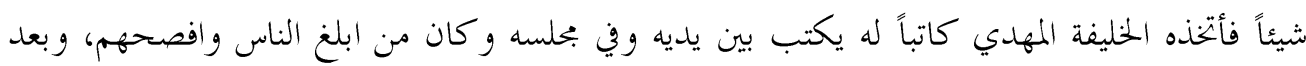

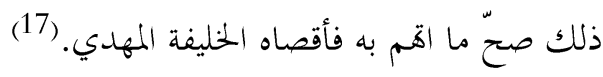

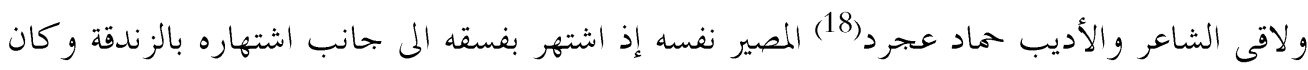

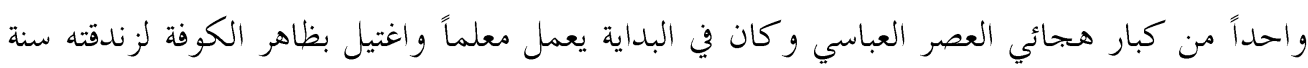

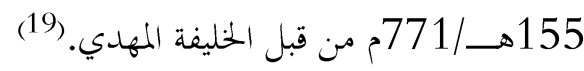


واستمر الخليفة المهاي بملاحقة الزنادقة والقضاء عليهم فهذا الشاعر المخضرم بشار بن برد(20) على

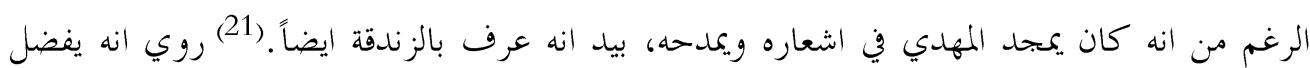
النار على الأرض ويؤيد فعل ابليس بعدم السجود لآدم، ونسبت اليه هذه الابيات: (22)

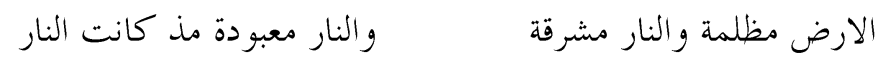

فأمر الخليفة المهادي بضربة سبعين سوطاً فمات من ذلك. (23)

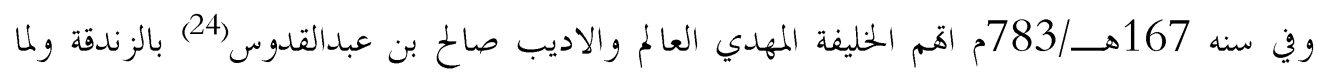
حضر بين يديه اعجب بعلمه وادبه وكثرة حكمته فأطلق سراحه ثم رده وسأله الست القائل:

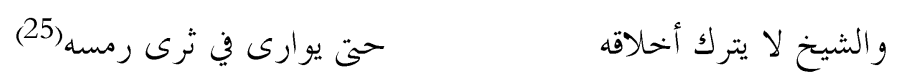

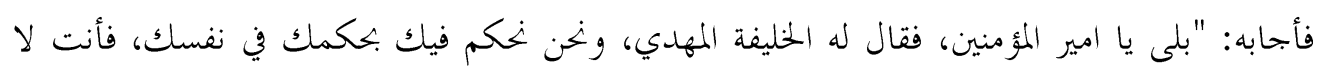

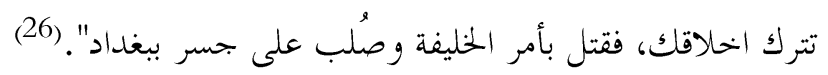

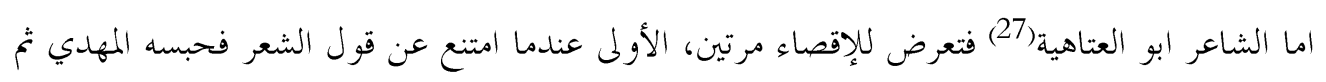

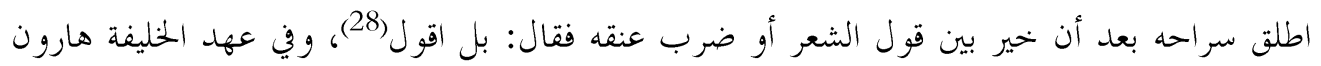

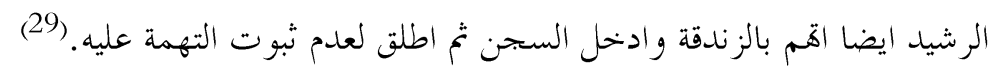

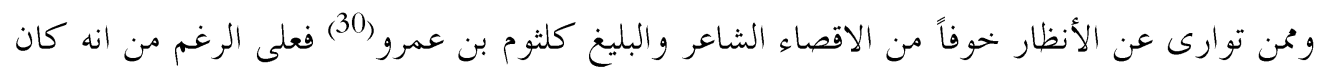

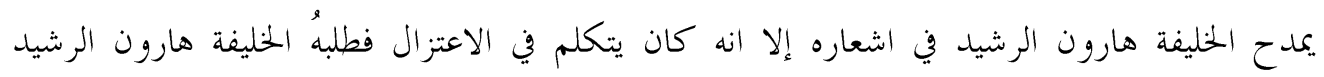

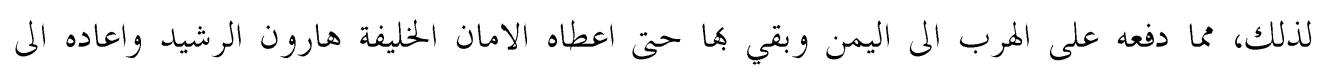
بغداد. (31) اما الشاعر الكبير ابو نؤاس(32) فأدخل السجن بأمر الخليفة الأمين وذلك لشربه للخمر وبقي محبوساً ثلاثة اشهر ثم تعهل بعدم شربا وقال: (33)

\section{لا لا اذوق المدامَ الا شميما}

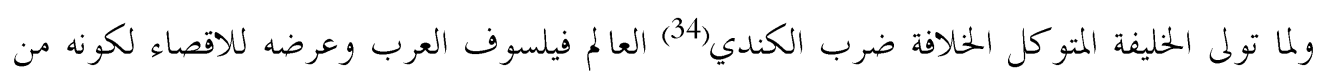

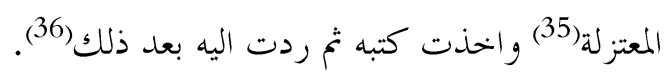

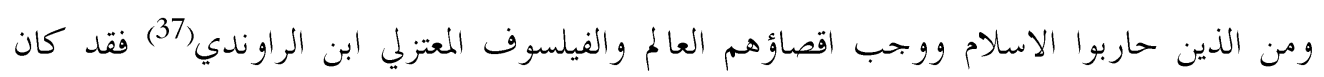

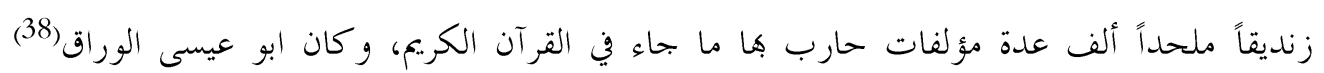

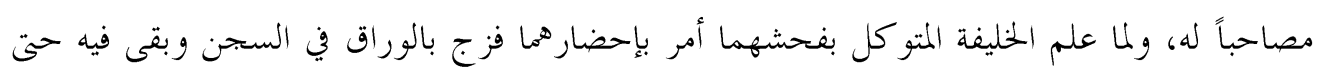


وفاته، اما ابن الراوندي فعاش طريداً الم ان مات بعد أن عاش عند رجل يهودي والف له كتاباً للرد على القر آن و سماه الدامغ للقر آن(39).

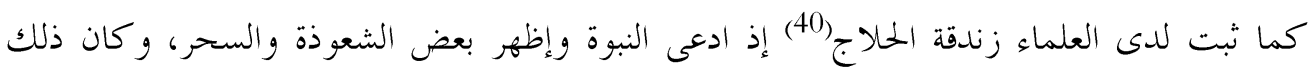

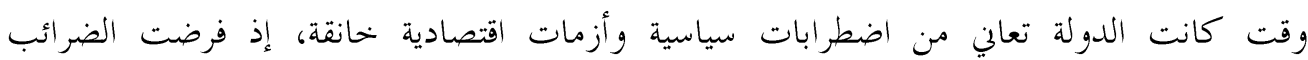

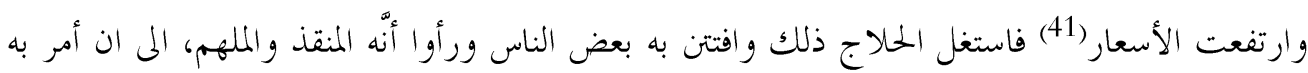

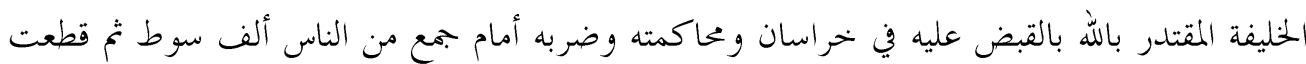

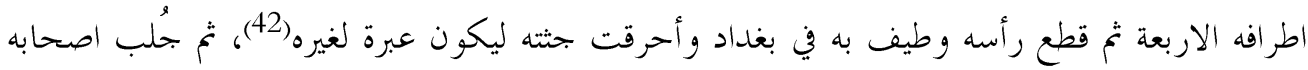

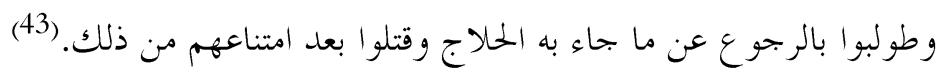

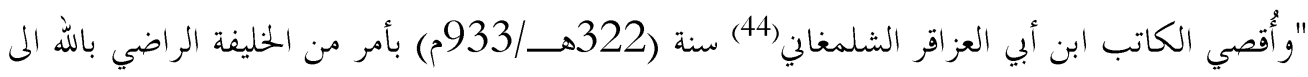

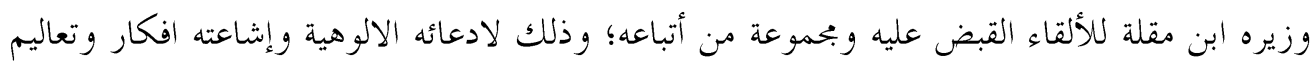

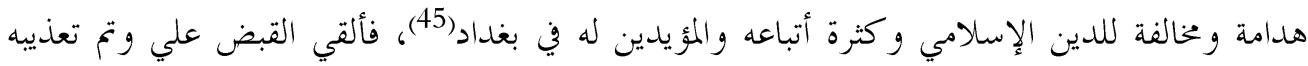

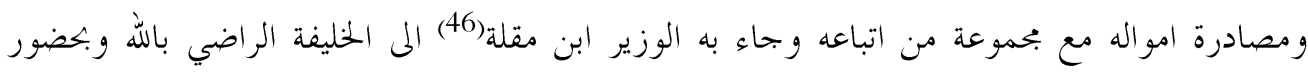

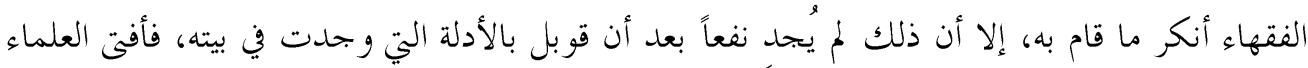

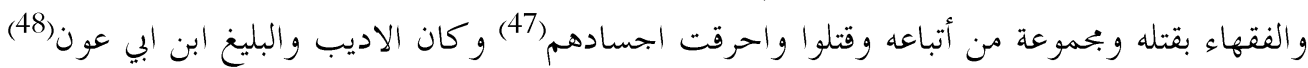

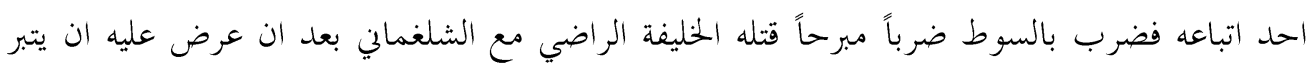

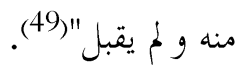
اما الشاعر ابن هاني الاندلسي(50) فقد اهمك في الملذات ورُميّه بالزندقة فنقم عليه أهل اشبيلية(51) مما دفع الى ابعاده عن البلاد. (52)

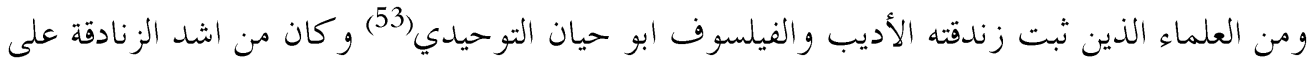

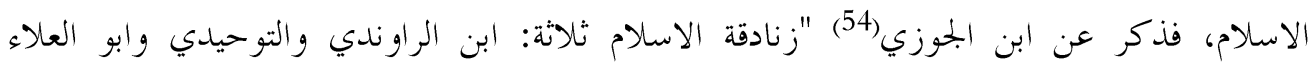

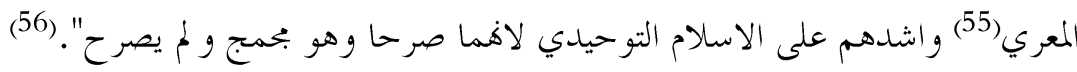

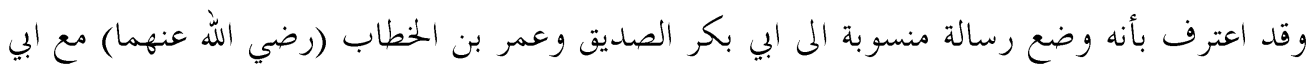

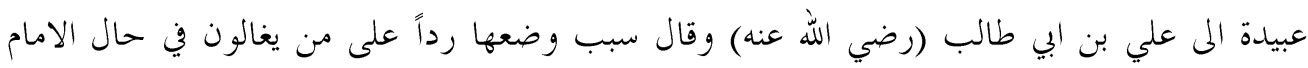
علي. (57) وذكر الذهبي "كان ابو حيان هذا كذاب قليل الدين تعرض لأمور جسام من القدح في الشريعة والقول بالتعطيل ولقد وقف الوزير الصاحب كافي الكفاة(58) على بعض ما ما كان يخفيه من سوض هو الاعتقاد فطلبه 
ليقتله، فهرب والتجأ الى اعدائه وفي بادئ الامر صدقو اقوله ثم عثروا على سوء عقيدته وما يبطنه من

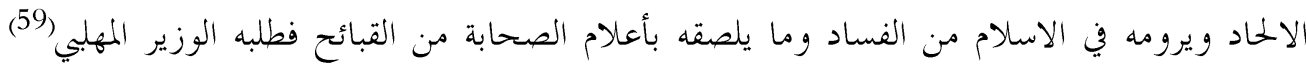
فأسستر منه ومات في الاستتار". (60) اما المتبيي(61) فقد تعرض لإققصاء مرتين الاولم ادعاءه النبوة وتبعه خلق كثير فأسر وادخل السجن مدة طويلة تم تاب من فعلته فأطلق سراحه، وفي الثانية سخط عليه عضد الدولة البويهي فدس اليه في الطريق

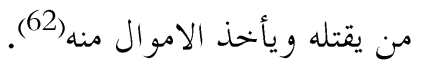
ولما شعر المتنبي بأمر قتله حاول الهرب فقال منال له غلام: كيف تفر تفر وانت القائل: و الطعن و الضرب و والقرطاس و القلم الخيل و الليل والبيداء تعرفين

فكر" راجعا فقتل (63). اما الأديب والكيميائي الطغرائي(64) رمي بالالحاد من قبل رلمبل بعض خصومه فقتل بأمر السلطان محمود

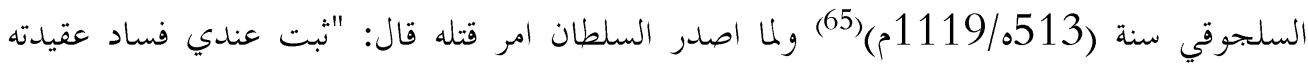
واتمه بالإلحاد"(66). وقد دفع الحسد والحقد فقهاء حلب الى ارسال محاضرة لصلاح الدين الايوبي اقموا فيها العالم والفقيه شهاب الدين السهروردي(67) بالكفر والفساد منا دفع صلاح الدين الايوبي الم ارسال رسالة لابنه بضرورة قتل السهروردي فقتل، اما السبب الذي دفع الفقهاء لذلك ان السهروردي بحث مع الفقهاء في مختلف المذاهب وعجزهم واخذ يكلمهم بكلام من هو اعلى منهم قدراً فتعصبوا عليه ووشوا به به. (68)

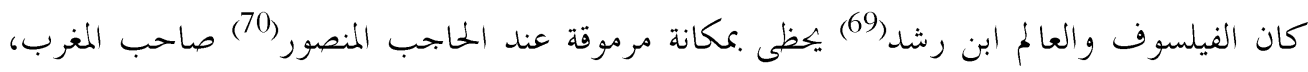
وصحح الكثير من النظريات والمفاهيم لعلماء كثيرون الأمر الذي دفع مناوئيه للسعاية فيه عند المنصور

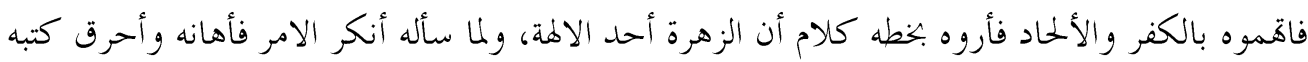
سوى كتب الطب و الهندسة ونفي من البلاد(71).

\section{ثانياً: محنة خلق القر آن}

تعد محنة خلق القرآن دافعاً سياسياً من اجل ضرب الخ الخصوم تحول بعدها ليكون قضية رأي عام ويصبح دافعاً دينياً عقائدياً من جهة وسياسياً من جهة اخرى، فأن الإقصاء الذي طال العلماء والفقهاء كان صنان

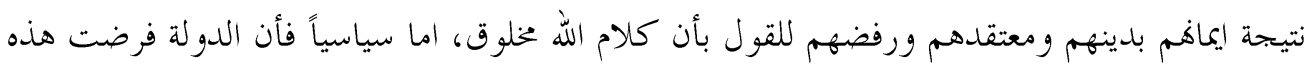
السياسة الجديدة وهي مقتنعة بتلك السياسة وعدم المو افقة عليها تعد دافعاً للسلطة لمو اجهة معارضيها. 
كما إنّ قضية خلق القرآن الكريم أصبحت تممة يوجهها بعض الخلفاء العباسيين مخالفيهم ومعارضيهم، لإلطاحة بهم أو نفيهم أو قتلهم. ففي سنة 833/0218م امر الخليفة المأمون اسحاق بن ابراهيم(72) بامتحان العلماء والفقهاء والقضاة

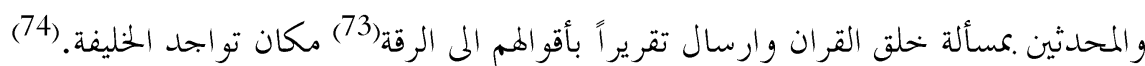
شرع اسحاق بامتحان العلماء والفقهاء فمن يقر بخلق القرآن تركه ومن يمتنع يتعرض للإقصاء(75).

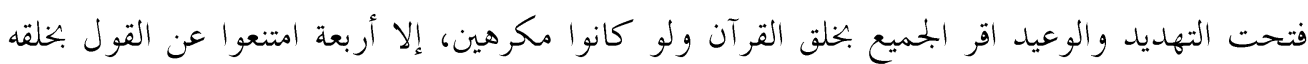

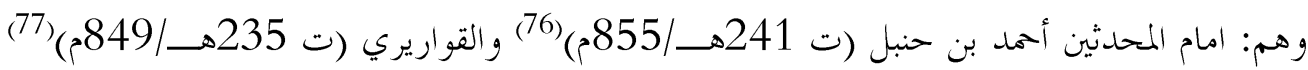

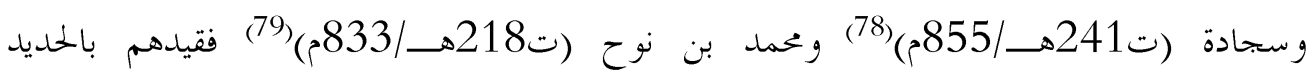
وأودعهم السجن. وسجادة. (10) وفي اليوم التالي دعاهم وهم مقيدون بالحديد فأعاد عليهم السؤال، وتحت الإهانة والخوف من الاقصاء

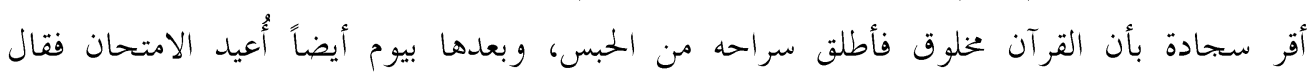

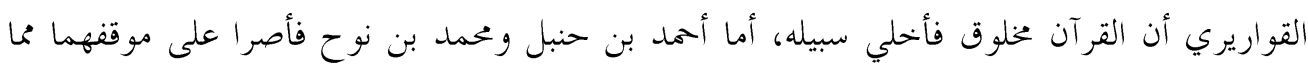
أدى إلى سجنهم و اقصاؤهم. (81) فحمل الأثنان مقيدان بالأغلال المثقلة محمولين على بعير واحد متوجهين المه طرسوس(82) محل تواجد

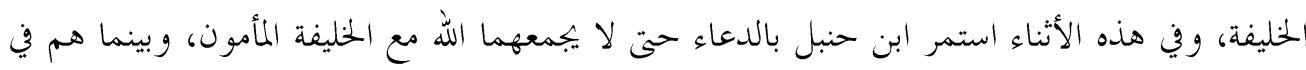

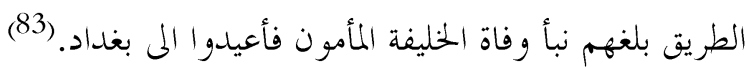

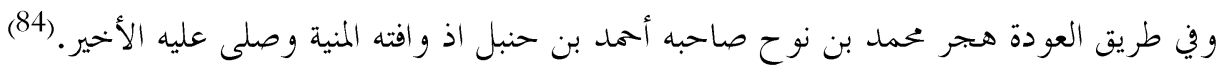

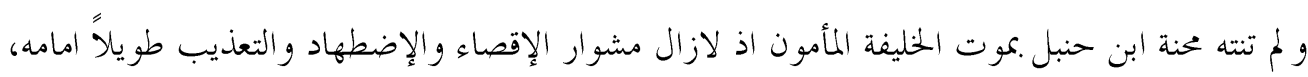

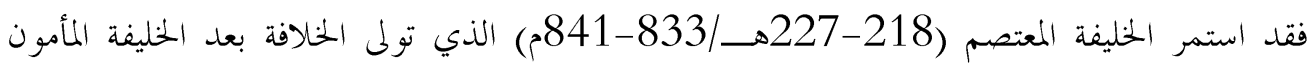

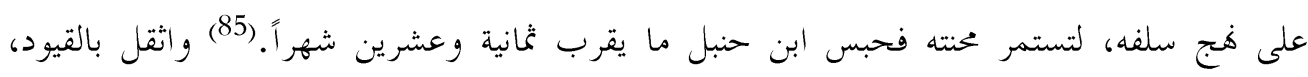

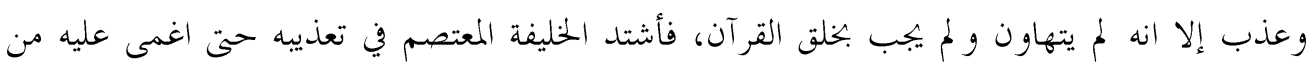

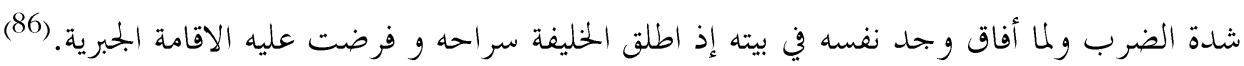

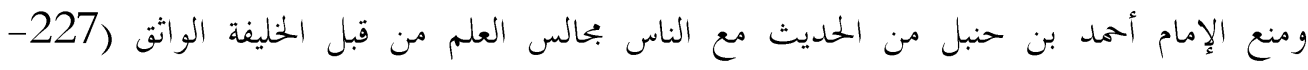

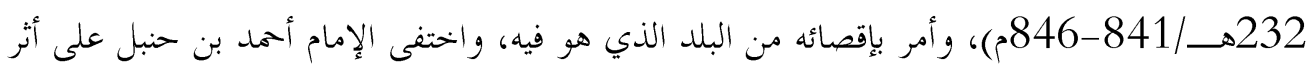
ذلك حتى وفاة الخليفة الواثق.87) 
وممن اختبر في محنة خلق القرآن أبو مسهر الدمشقي (ت218هــ833م)(88) حمله الخليفة المأمون من

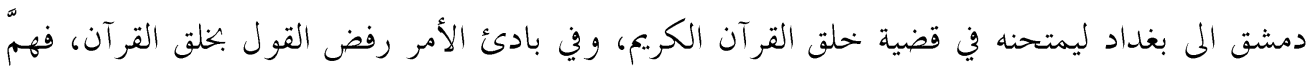

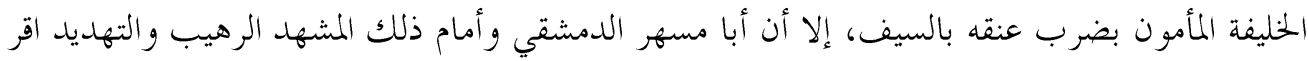
بخلق القر آن و كان جوابه هذا تحت وطأة التهديد فتراجع الخليفة المأمون عن قتله فأودع بالسجن الم الى ان فارق الخياة. (89)

وللسبب ذاته اقصيّ الفقيه والمحدث ابن مسكين(90) الذي حمل الى بغداد أيضاً و لم يقر بخلق القرآن

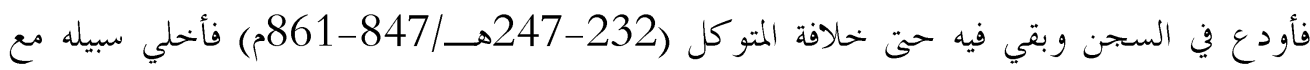

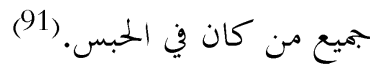
وكذلك الامام العلامة المحدث بشر بن الوليد(92) تعرض للإقصاء أيضاً بعد ان سعى به رجل الى الخليفة

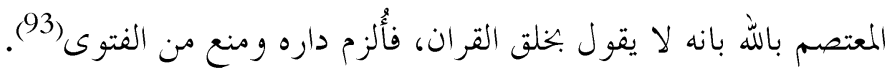

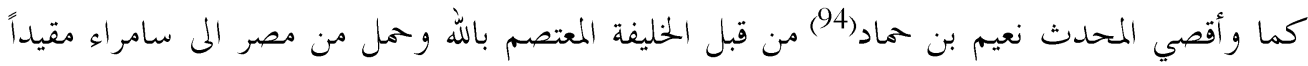
وسجن لامتناعه عن القول بخلق القرآن وبقي بالسجن حتى وفاته واوصى أن يدفن بقيوده(

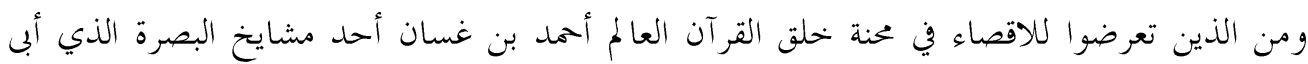

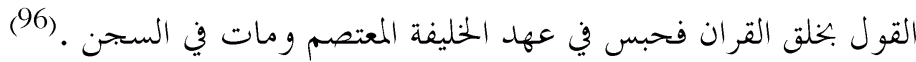

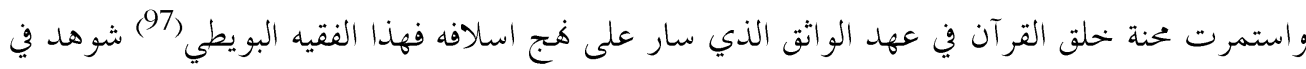

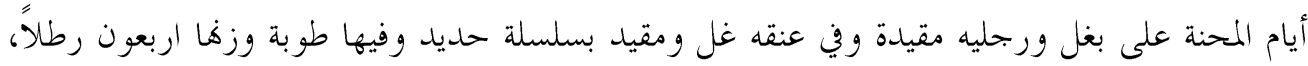

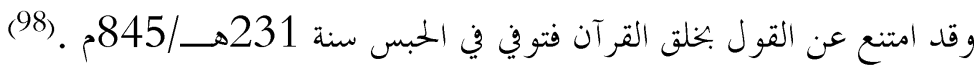

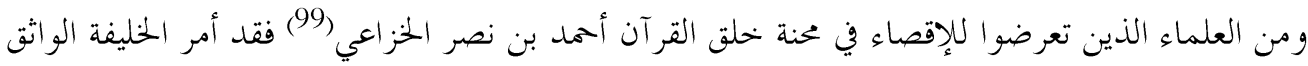

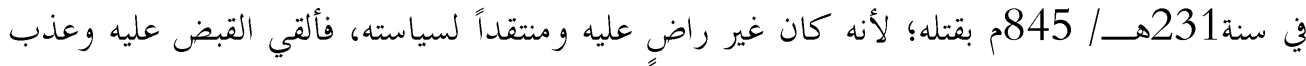

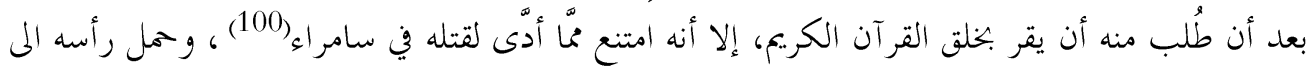

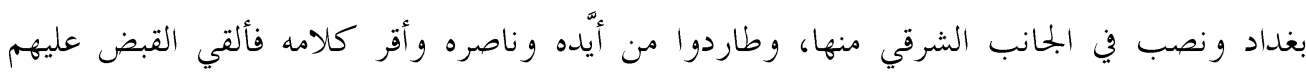
ووضعوا في السجون ومنعت عنهم الزيارة(101).

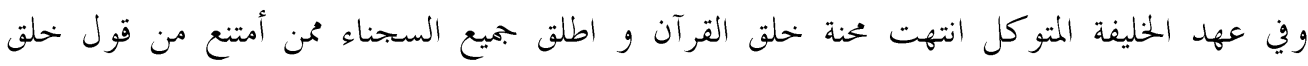
القر آن(102). وتر كت هذه المحنة اثار آ كبيرة على الدولة العربية الإسلامية. 
بعد ان وصلنا الى هاية دراستنا الموسومة بــ(الاسباب والدوافع الدينية لظاهرة اقصاء العلماء في الدولة العربية الاسلامية في العصر العباسي) اتضحت لدينا عدة نتائج ولعل من ابرزها:

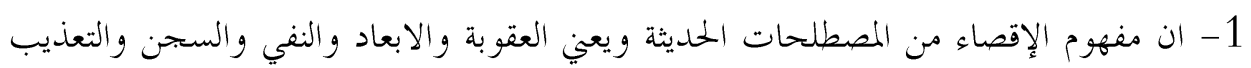
و التهجير والاقامة الجحبرية...الخ وهذا ماذهبت اليه من دراسة.

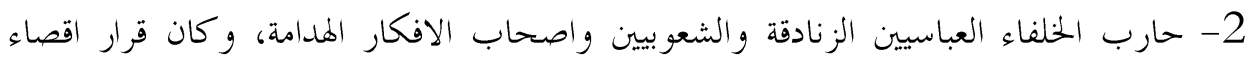

هؤلاء صائباً، لما فيها من أفكار من شأها هدم المجتمع الاسلامي طمس هو يته وابنه العربية.

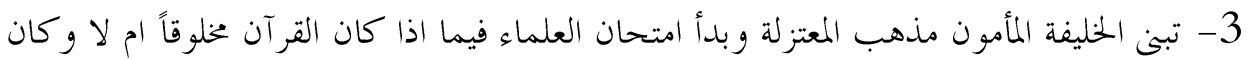

$$
\text { الدافع من وراء ذلك لضرب كافة المعارضين للدولة. }
$$

4- خسرت الدولة العربية الاسلامية العديد من العلماء الكبار نتيجة سياسة خاطئة اتبعها الخليفة المأمون ومن جاء بعده من الخلفاء.

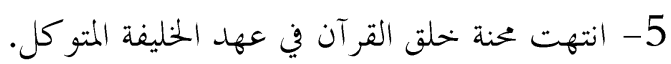

6- تنوع حالات الاقصاء التي تعرض لها العلماء فبضعهم أدخل الحبس وبعضهم قتل والبعض

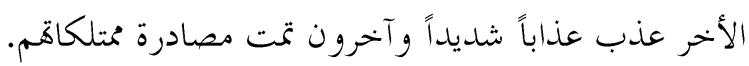

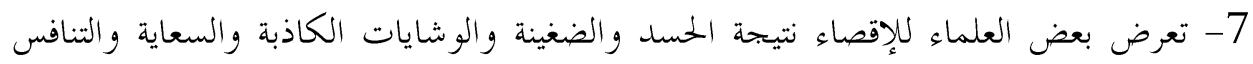

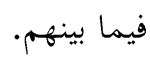

8- أُحرقت كتب بعض العلماء التي احتوت افكارا هدامة.

1. ابن الاثير، عز الدين ابو الحسن علي بن ابي الكرم (ت630هـ/1232م)، الكامل في التاريخ، تح: عمر عبد السلام تدمري، ط1، دار الكتاب

$$
\text { العربي، بيروت، 1997م. }
$$

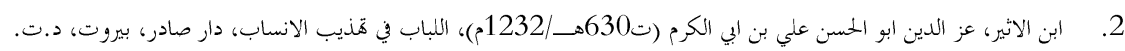

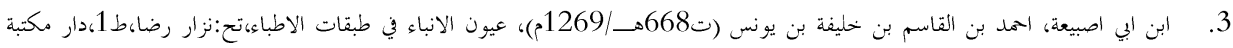

$$
\text { الحياة، بيروت،دوتت }
$$

4. البلاذري، احمد بن يهيى بن جابر بن داود (ت (ت279هـ/892م)، أنساب الأشراف، تح: عبد العزيز الدوري، جمعية المستشرقين الالمانية،

$$
\text { بيروت، 1978م. }
$$

ابن تغري بردي، ابو المحاسن جمال الدين يوسف (ت874هــ/1469)م)، النجوم الزاهرة في ملوك مصر والقاهرة، وزارة الثقافة والارشاد، دار 
ابن الجوزي، ابو الفرج عبد الرحمن بن علي(ت597هـ/1200م)، المنتظم في تاريخ الملوك والامم، تح: محمد عبد القادر عطا-مصطفى عبد

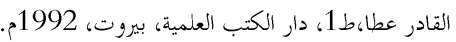

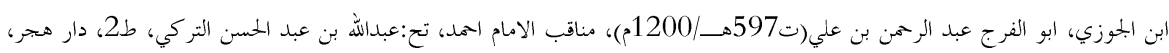

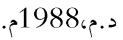

ابن حبان، ابو حاتم محمد بن حيان بن احمد (ت 354هـ/1965م)، الثقات، تح: محمد عبد المفيد جان، ط1 1973، دار المعارف العثمانية، حيدر .10

اباد، 1973م. 1973

ابن حجر العسقلالي، ابو الفضل احمد بن علي بن محمد بن احمد (ت852هـ/1448م)، لسان الميزان، تح: عبدالفتاح ابو غدة، ط1، دار البشائر الاسلامية، 2002 2002.

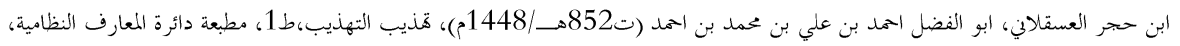

المند، 1907م.

ابن حجر العسقالي، ابو الفضل احمد بن علي بن محمد بن احمد (ت852هـ/1448م)، رفع الاصر عن قضاة مصر، تح: علي محمد عمر،

ط1، مكتبة الخابحي، القاهرة، 1998.

ابن حزم، ابو محمد علي بن احمد بن سعيد (456هــ/1063م)، جمهرة أنساب العرب، تح: لجنة من العلماء، 1983، دار الكتب العلمية، بيروت،

1983م.

الخطيب البغدادي، ابو بكر احمد بن علي بن ثابت بن احمد بن مهدي (ت463هـ/1070م)، تاريخ بغداد، تح: مصطفى عبد القادر عطا،

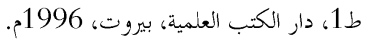

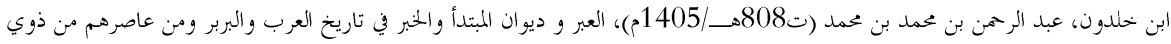

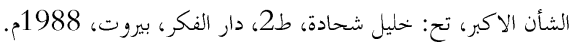

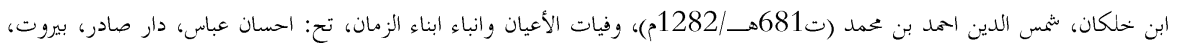

1900م.

ابن دريد، ابو بكر محمد بن الحسن (ت 321هـ/9331)، جهمة اللغة، تح: رمزي منير بعلبكي، طـ، دار العنم للماليين، بيروت، 1987م.

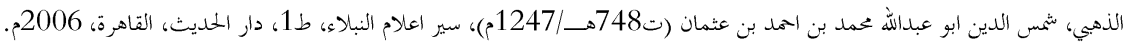

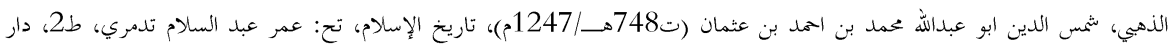

الكتاب العربي، بيروت، 1993م.

الذهبي، شمس الدين ابو عبدالله عمدل بن احمد بن عثمان (ت748هــ/1247م)، ميزان الاعتدال في نقد الرجال، تح: علي محمد البجاوي،

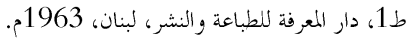

الزبيدي، ابو الفيض محمد بن عبد الرزاق (ت 1205هــ/1790م)، تاج العروس من جواهر القاموس، تح: بحموعة من المحققين، ط1، دار

الهداية، د.م، د.ت.

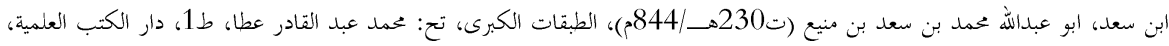

$$
\text { بيروت، 1990م. }
$$

ابن السكيت، ابو يوسف يعقوب بن اسحاق (ت 244هــ/858م)، اصلاح المنطق، تح: محمد مرعب، طرو، دار احياء التراث، بيروت،

2002

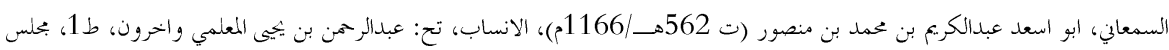

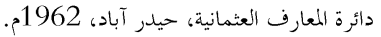

26. السيوطي، جلال الدين عبد الرحمن بن ابي بكر (ت دائرة 1505/0911م)، تاريخ الخلفاء، تح: حمدي الدمرداش، ط1،، مكتبة نزار مصطفى الباز،

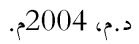

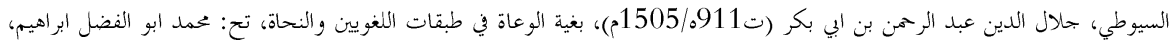

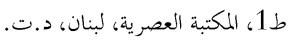

28. الصفدي، صلاح الدين خحليل بن ايبك بن عبدالله (ت1362/.764م)، الوافي بالوفيات، تح: الارناؤوطــتركي مصطفى، ط1، دار صادر،

بيروت، 2002 2002

الطبري، ابي جعفر محمد بن جرير(ت310/022/0)، تاريخ الرسل والملوك، ط2، دار الكتب العلمية، بيروت، 2003م. 


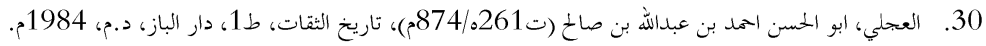

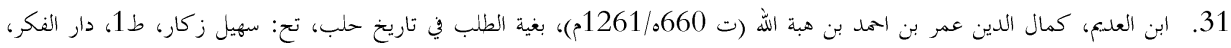
2.

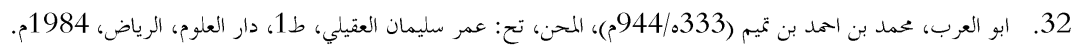

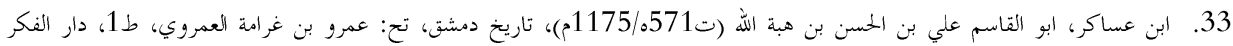

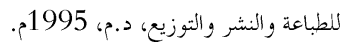

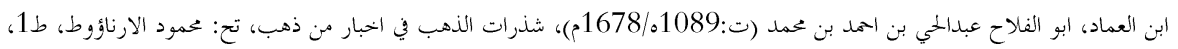

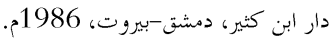
ابن فارس، ابو الحسين احمد بن فارس بن زكريا (ت 1979 1004/.395م)، معجم مقاييس اللغة، تح: عبدالسلام عحمد هارون، ط1، دار الفكر،

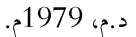

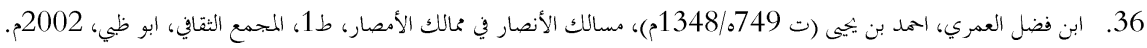

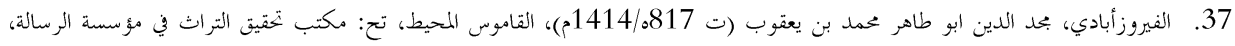

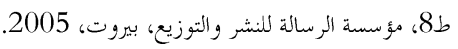

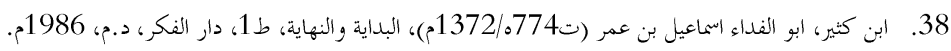

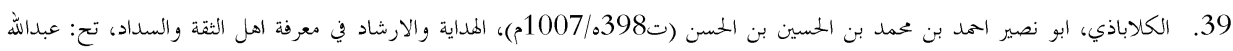

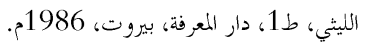

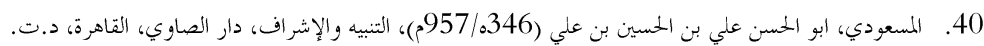

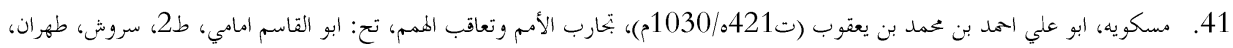
2000

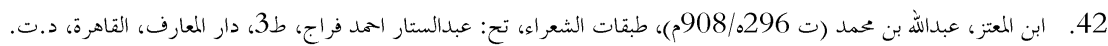

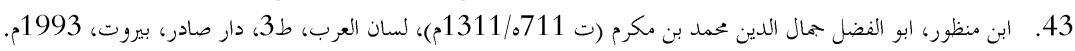

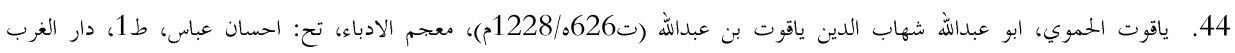

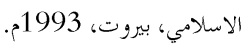

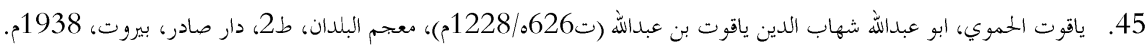

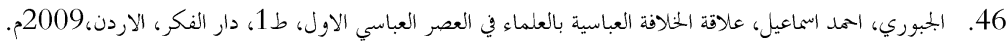

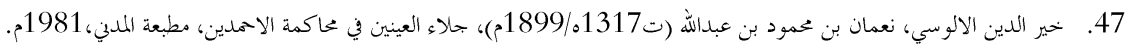

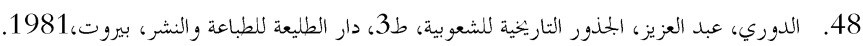

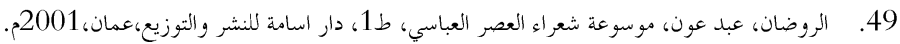

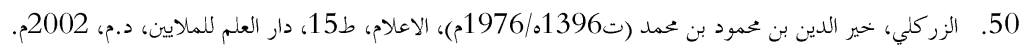

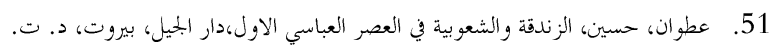

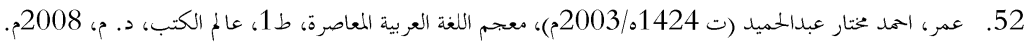

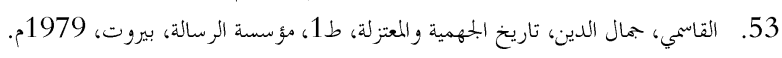

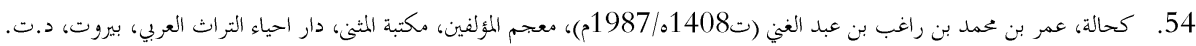

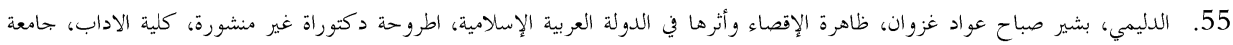
الانبار، 2019. 


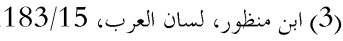

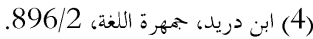

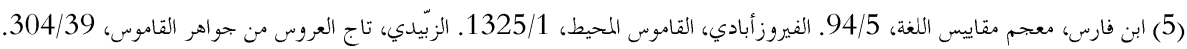

(6) عمر، معتم اللغة العربية المعاصرة، 225/1.

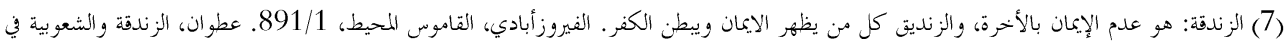

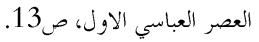

(8) الشعوبية: عاولة الحط من العرب، وانكار فضلهم على غيرهم. ابن منظور، لسان العرب، 500/1. ينظر: الدوري، الجذور التاريخية للشعوبية، ص9 9 ومابعدها.

(9) عطوان، الزندقة والشعوبية في العصر العباسي الاول، صان 149 وما بعدها. الدوري، الجذور التاريخية للشعوبية، ص11.

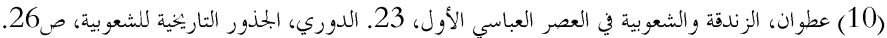

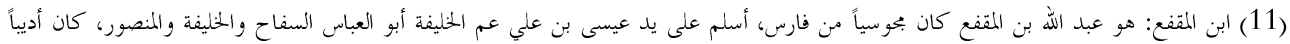

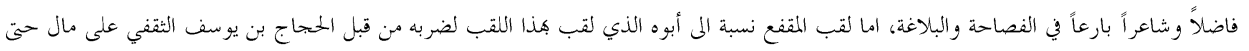

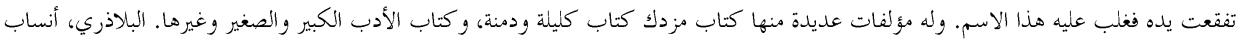

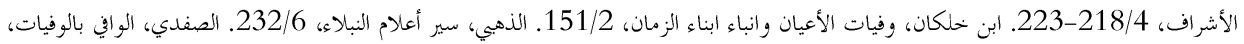

.242-239/17

196/10) ابن كثير، البداية والنهاية، 196/10.

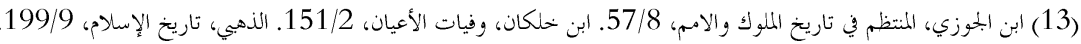

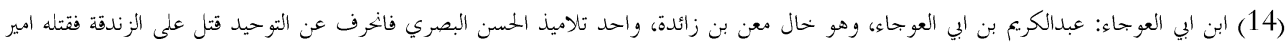

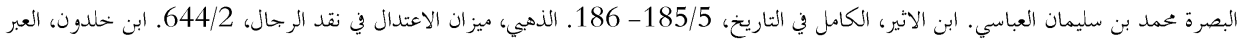

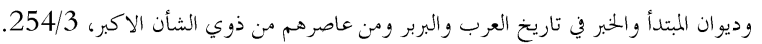

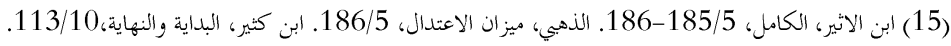

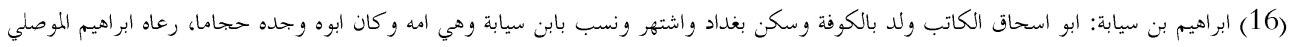

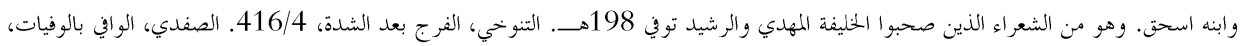

(17) الصفدي، الوافي بالوفيات، 11/6. الروضان، موسوعة شعراء العصر العباسي، 13/1-114.

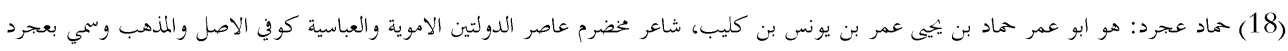

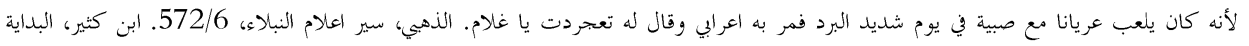

والنهاية،114/10.

296/8 296/ ابن خلكان، وفيات الاعيان، 213/2.

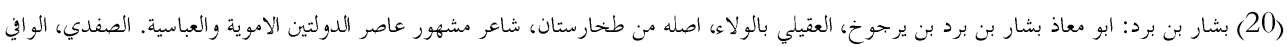
بالوفيات، 85/10.

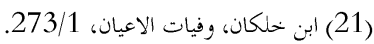
(22) ابن العماد، شذرات الذهب في اخبار من ذهب، 301/2.

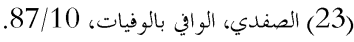
(24) صالخ بن عبد القدوس: ابو الفضل صالخ بن عبد القدوس بن عبد الله القدوس البصري واشتهر بشعر الحكمة والامثال والمواعظ. ابن خلكان، وفيات الاعيان، 492/2.

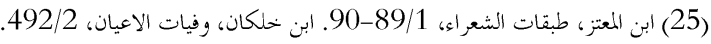
(26) (25) ابن المعتز، طبقات الشعراء، 90. 
(27) ابو العتاهية: أبو أسحاق أسماعيل بن القاسم العتري، لقب ابو العتاهية لاضطراب كان فيه، وهو احد فحول الشعراء نسك في اخر حياته، ومال للوعظ. ابن خلكان، وفيات الاعيان، 249/6.

(28) (28) ابن العماد، شذرات الذهب، وفيات الاعبان، 53/3.

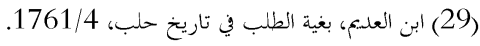
(30) كلثوم بن عمرو: أبو عمرو كلثوم بن عمرو بن ايوب العتابي التغبي، شاعراً من قسرين (ت220ة). ياقوت الحموي، معجم الادباء، 2243/5-

(31) ابن خلكان، وفيات الأعيان، 122/4. (32) ابو نؤاس: أبو علي الحسن بن هاني الحكمي، رئيس الشعراء ومدح الحلفاءو والوزراء. الذهبي، سير اعلام النبلاء، 48/8.

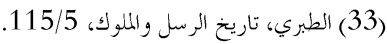

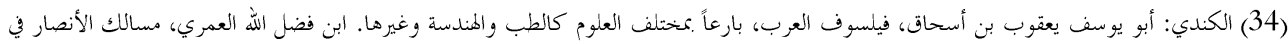

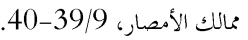
(35) المعتزلة: هي فرقة كلامية ظهرت في بداية القرن الثاني المجري في البصرة في أواخر العصر الأموي وازدهرت في العصر العباسي وغلبت عليهم التزعة

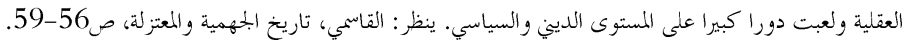

244/13.

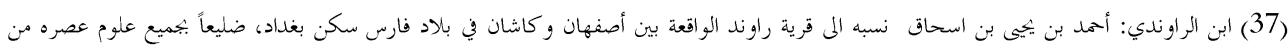

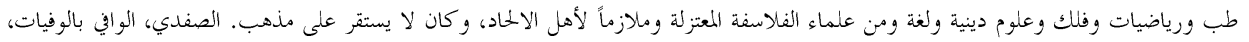

.154-151/8 (38) أبو عيسى الوراق: هو محمد بن هارون الوراق من أهل بغداد وتوفي فيها وكان من شيوخ المعتزلة، وكان أستاذ وصديق ابن الراوندي. الذهبي، تاريخ

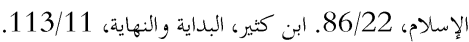

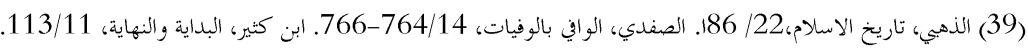

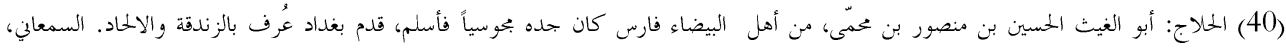

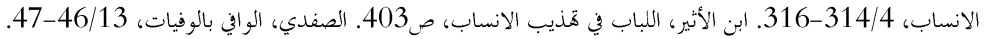

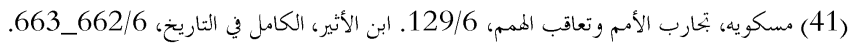

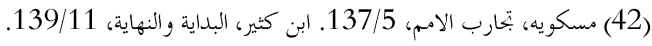

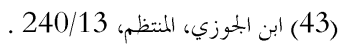

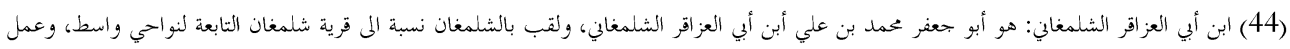

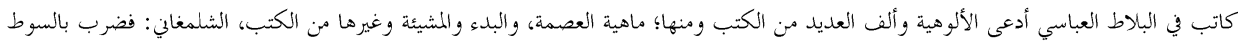

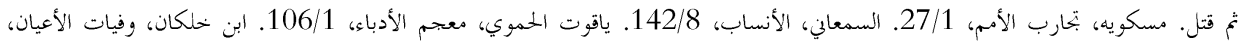

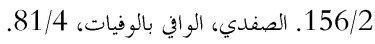

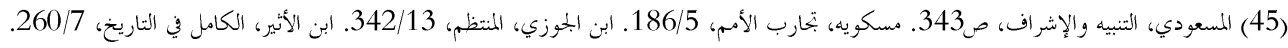

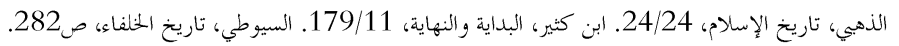

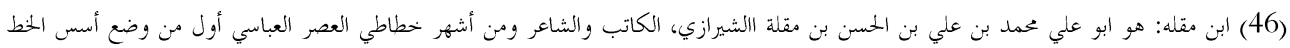

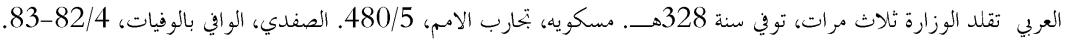

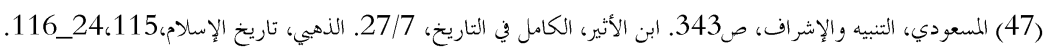

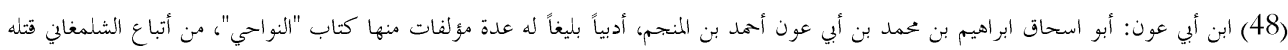

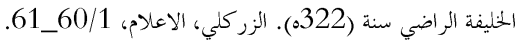

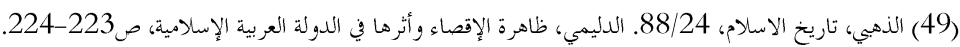

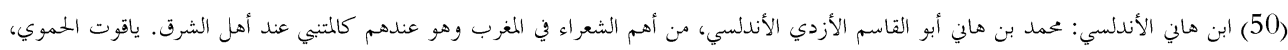
2667/6. 
(51) أشبيلية: مدينة كبيرة في الأندلس، على ضفاف هر الوادي الكبير، أشتهرت بزراعة القطن. ياقوت الحموي، معجم البلدان، 195/1. (52) ابن خلكان، وفيات الأعيان، 421/4.

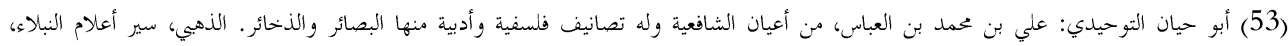

.548-547/12

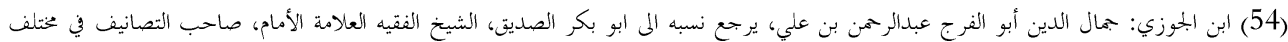

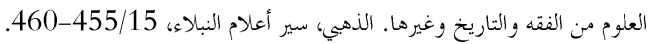

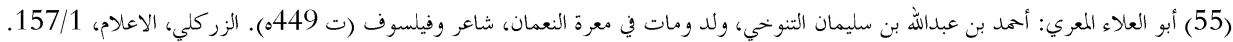

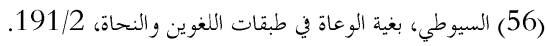
55/9 57)

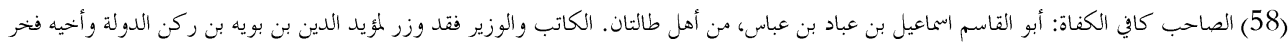
الدولة، (ت 385ه). ياقوت الحموي، معجم الأدباء، 662/2-663.

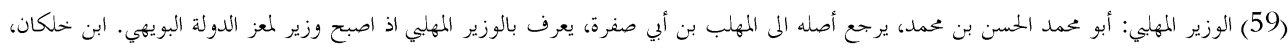
وفيات الأعيان، 124/2. 547/12.

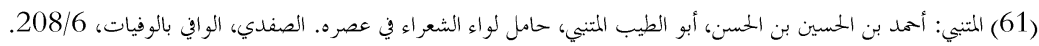
(62) ابن كثير، البداية والنهاية، 257/11.

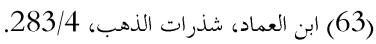

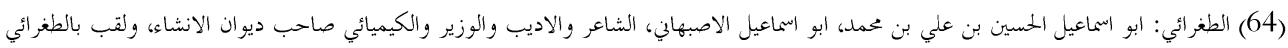

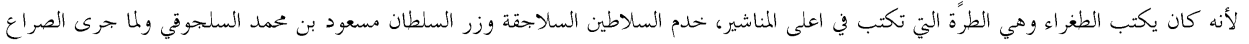

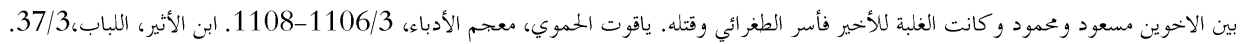

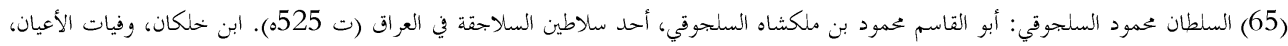

.183-182/5

(66) ياقوت الحموي، معجم الأدباء، 1106/3-1108. ابن الأثير، اللباب، 37/3. ابن خلدون، العبر وديوان المبتدأ والخبر، 59/5.

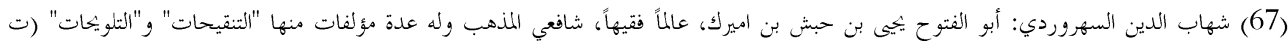
587ه). ابن خلكان، وفيات الأعيان، 6 / 268-273.

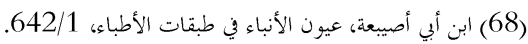

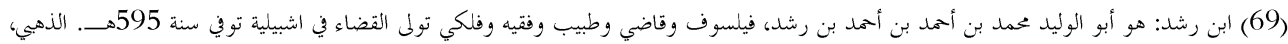

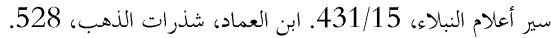

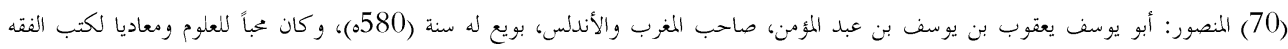
والرأي. ابن العماد، شذرات الذهب، 525/6.

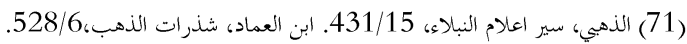

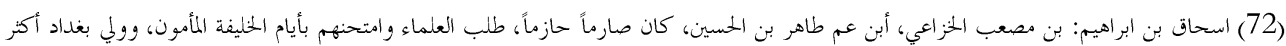

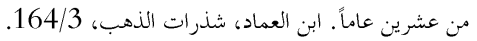

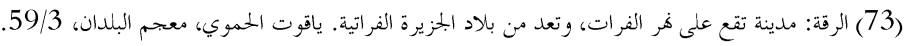

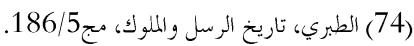

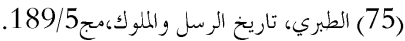

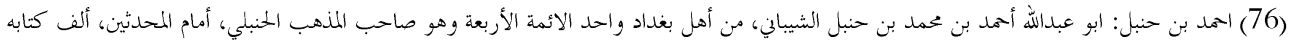

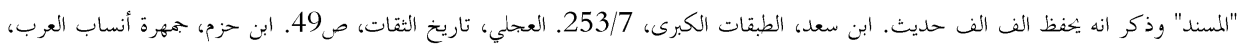




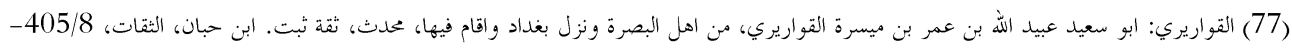

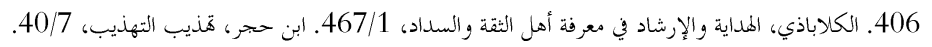

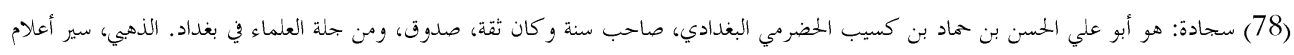

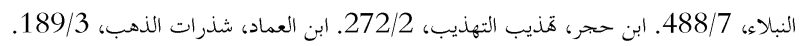

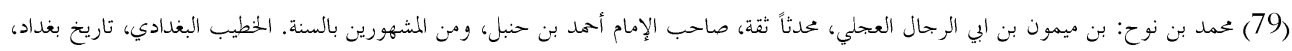

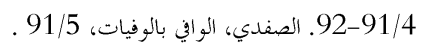

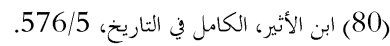

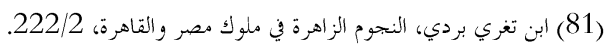

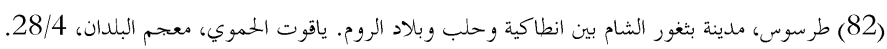

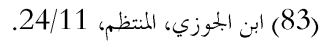

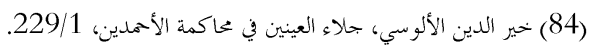

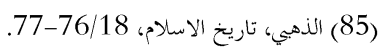

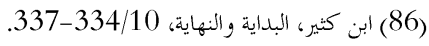

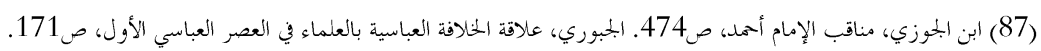

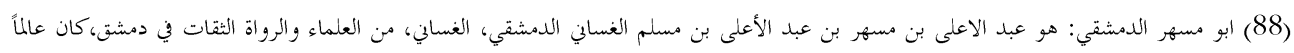

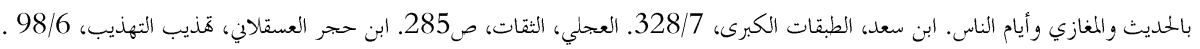

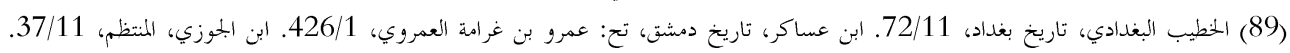

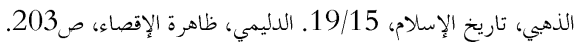

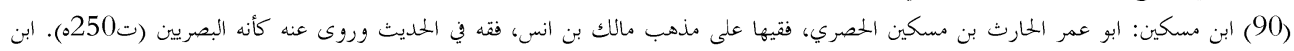

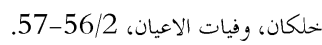

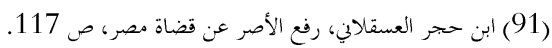

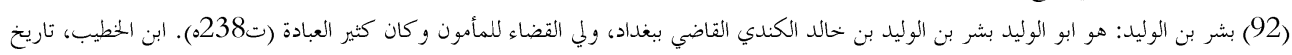
بغداد، 83/7-84.

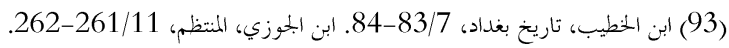

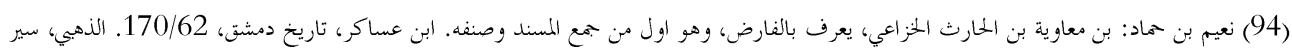

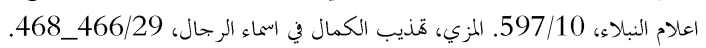

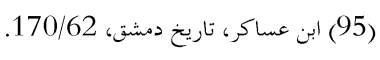

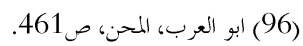
(97) البويطي: ابو يعقوب يو سف بن ئيى، سيد الفقهاء، كان الشافعي يقربه وجلس بعده في مكانه. الذهبي، سير أعلام النبلاء، 459/9.

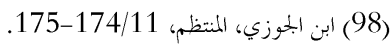

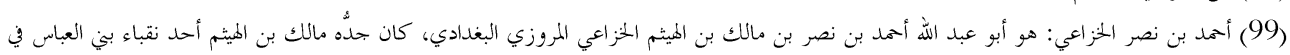

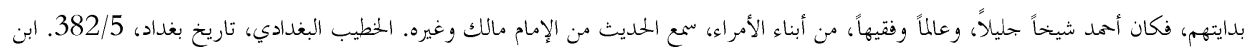

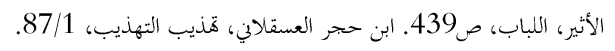

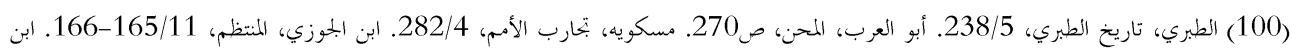

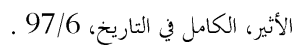

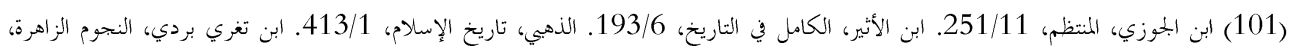

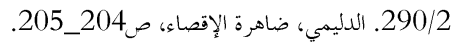
(102) ابن تغري بردي، النجوم الزاهرة، 290/2. 